\title{
REPORT OF THE NATIONAL ADVISORY COMMISSION ON GIVIL DISORDERS: A REVIEW ARTICLE
}

\author{
Vernon M. Briggs, Jr.
}

On March 1, 1968, the National Advisory Commission on Civil Disorders made public its findings concerning the nature, causes, and solutions to the violence which rocked many of the nation's cities during the "long, hot summer" of 1967. ${ }^{2}$ The basic conclusion of the Report is: "Our nation is moving toward two societies, one black, one white-separate and unequal" (p. 1). The main culprit is said to be "white racism." Tom Wicker, of the New York Times, writes in the introduction to the Report: "What had to be said has been said at last." Although the conclusion is not new, what is surprising and encouraging is that a national commission composed exclusively of moderates would reach such a conclusion unanimously and would express its findings so effectively."

As an indictment of American ghettos, the Report promises to rank as a classic alongside Jacob Riis's How the Other Half Lives. Writing at the turn of this century, Riis found the ghettos to be mainly ethnic and religious; today, they are largely racial. Negroes preceded the ethnicreligious minorities of Riis's ghettos to this country by many decades and even centuries. Yet the "late comers" are now largely assimilated into the mainstream of American life while Negroes are now the heirs to the slums. Aside from the disclosure of squalor amidst affluence, the Report is further documentation of the fact that the American Negro has yet to become the Negro American.

The immediate impetus for the study was the occurrence of major outbreaks of violence during the summer of 1967. The Commission was

The author is Associate Professor of Economics, The University of Texas at Austin. He wishes to express his indebtedness to his colleague, Daniel C. Morgan, for detailed comments on an earlier version of this review article.

${ }^{1}$ Report of the National Advisory Commission on Civil Disorders, New York, Bantam Books Inc., 1968, p. 609. All page references contained in the body of this paper refer to this edition of the report.

${ }^{2}$ The members were Otto Kerner (Governor of Illinois), Chairman; John V. Lindsay (Mayor of New York City), Vice Chairman; Fred R. Harris (Senator from Oklahoma); Edward W. Brooke (Senator from Massachusetts); James C. Corman (Congressman from California); William M. McCulloch (Congressman from Ohio); I. W. Abel (President, United Steelworkers of America); Charles B. Thornton (Chairman of the Board of Litton Industries); Roy Wilkins (Executive Director, National Association for the Advancement of Colored People); Katherine G. Peden (Commissioner of Commerce, State of Kentucky); and Herbert Jenkins (Chief of Police, Atlanta, Georgia). 
requested to answer three basic questions: What happened? Why did it happen? What can be done?

\section{WHAT HAPPENED}

After careful review, the Commission listed 164 disorders which occurred in 128 cities during 1967. Of this number, 41 disorders in 39 cities were classified as either "major" or "serious." The other 123, about 75 percent of the total, "were relatively minor and would not have been regarded as nationally newsworthy 'riots' in previous years" (p. 113). In all these disorders, 83 people were killed, and 1,897 were injured. Approximately 16,000 citizens were arrested and 100 million dollars of damage done to property. Most of the deaths (80\%), injuries (50\%), arrests $(75 \%)$, and property damage $(55 \%)$ resulted from events in two cities-Newark and Detroit.

Eighty-three percent of those arrested were Negroes. However, the interviews of rioters conducted by the Commission in 20 cities "indicate that almost all rioters were Negroes" (p. 129). The profile of the "typical rioter" is quite revealing. He was an unmarried Negro male between the ages of 15 and 24 . He was not a migrant from the South; on the contrary, he was born in the state and was a lifelong resident of the city where the riot occured. He was employed, but in a menial or low-status job. He felt that he was barred from better employment opportunities by discriminatory practices of employers. He was proud of his race and was hostile not only to whites but also to middle-class Negroes. Although he was "likely to be actively engaged in civil rights efforts," he was extremely distrustful of the political system and political spokesmen.

Prior to the Commission's Report, it was popular to assert that the rioters were from among the unemployed or the marginally employed poor. $^{3}$ The findings of the Commission refute this contention. A detailed study of 500 riot prisoners by the Department of Labor determined that the typical arrestee "was a blue collar worker in a manufacturing plant where he earned about $\$ 120$ a week." The Commission found no difference in the employment status of rioters and non-rioters in the same community. It would seem, therefore, that a distinction between the non-working poor, that is, the so-called "lumpen-proletariat," and the conventional working class is not a useful distinction for understanding participation in the riots of 1967.

What about conspiracy as a cause of these riots? The Report is

${ }^{3}$ For example, see Bayard Rustin, "A Way Out of the Exploding Ghetto," Negroes and Jobs, edited by Louis A. Ferman et al., Ann Arbor, 1968, pp. 523-524.

'The Detroit Riot ... A Profile of 500 Prisoners, U.S. Department of Labor, Washington, D. C., 1968 . Quoted in the Report. 
adamant: The riots "were not caused by, nor were they the consequence of, any organized plan or 'conspiracy'" (p. 202). The Commission could uncover "no evidence that all or any of the disorders or incidents that led to them were planned or directed by any organization or group, international, national, or local" (p. 202). Most certainly, the disorders resulted from accumulated frustration and bitterness-in turn the results of discrimination, prejudice, disadvantaged conditions, intense and pervasive grievances, and tension-heightening incidents-combined with the volatile presence of large numbers "of youthful politically aware activists." This combustible mixture led to the spontaneous eruptions in the cities studied. The Report makes the analogy more precise by asserting that the explosive material in the ghettos is more similar to liquid nitroglycerin than to sticks of dynamite. Someone need not actually ignite a fuse. Even a minor jolt can release the full force of the latent charge. The incident could be a fight between two women over a wig (as in Minneapolis), a raid on a "blind pig" (as in Detroit), or the arrest of a man carrying a beer can in a shopping center (as in Atlanta).

\section{WHY DID IT HAPPEN?}

After the riots, some analysts offered the explanation that the disorders were rebellions, not riots, led by rebels with a cause, not by rioters without purpose. The Commission grapples with this issue, but somewhat ambiguously. At one point in the Report the events in Detroit are described as follows: "A spirit of carefree nihilism was taking hold. To riot and to destroy appeared more and more to become ends in themselves" (p. 91). Yet, the Report later contends that "most of those who attacked white authority and property seemed to be demanding fuller participation in the social order and material benefits enjoyed by the vast majority of American citizens" (pp. 110-111).

The Commission points out clearly that the 1967 disorders were not race riots as the term is usually understood (p. 365). Almost all of the deaths, injuries, and damages occurred within predominantly Negro districts. The "integrated looting" in Detroit adds further credence to this contention, as does the fact that "public institutions generally were not targets" (p. 116). There was, however, some evidence of deliberate destruction of white-owned businesses in ghettos (p. 116). But again, "the fact that most of the merchants who operate stores in almost every Negro area are white" (p. 274) leaves few alternative targets for looters. It does seem, therefore, that these were riots of frustration and not rebellions with a goal.

Before the Commission could recommend solutions, it had to pinpoint the precise sources for the omnipresent frustrations of the black ghettos. The Report states that "the causes of the recent racial disorders are 
imbedded in a massive tangle of issues and circumstances-social, economic, political, and psychological-which arise out of the historical pattern of Negro-white relations in America" (p. 203). To interpret the present and predict the future, it is necessary to review the past. The Commission briefly sketches the role that has been played by the leaders, organizations, and philosophies of the Negro protest movement over the years and concludes with this observation:

The central thrust of Negro protest in the current period has aimed at the inclusion of Negroes in American society on a basis of full equality rather than at a fundamental transformation of American institutions. There have been elements calling for a revolutionary overthrow of the American social system or for a complete withdrawal of Negroes from American society. But these solutions have had little popular support. Negro protest, for the most part, has been firmly rooted in the basic values of American society, seeking not their destruction but their fulfillment."

Indeed, the events of the 1960 s have made the civil rights movement the most "in" movement in the history of social protests. The objectives of the sit-ins, pray-ins, wade-ins, sleep-ins, teach-ins, and stall-ins have all been toward the direction of inclusion and not exclusion. As Dr. Martin Luther King was fond of saying, "The blacks and whites of this country are bound together into a common garment of destiny."

Quite contrary to some of its political critics, the Commission in its Report strongly condemns those in the black community who advocate withdrawal from American society.

The Black Power advocates of today consciously feel that they are the most militant group in the Negro protest movement. Yet they have retreated from a direct confrontation with American society on the issue of integration and, by preaching separatism, unconsciously function as an accommodation to white racism. Much of their economic program, as well as their interest in Negro history, selfhelp, racial solidarity, and separation is reminiscent of Booker $T$. Washington. The rhetoric is different but the programs are remarkably similar.

However, except for a general interest in their cultural heritage, black leaders are difficult to understand or to take seriously when they look to recent African experience for solutions to the racial problems of this country. In Africa, the revolutionary movements of the postwar period have been characterized by the black majority's rebelling against long suppression by a white minority. In the United States, the reverse is true: the white majority oppresses the black minority. The American

${ }^{5}$ Report on Civil Disorders, p. 236.

Ibid., p. 235. 
situation here is a classic case of the fear expressed by Alexis de Toqueville in his Democracy in America of 1835 concerning the potential "tyranny of the majority." Africa offers no similar example for black inspiration. Moreover, in Africa this year more blacks will be killed by other blacks than were ever murdered by whites in this country. The estimate is that at least 40,000 Ibos were killed in the past year, and it is highly likely that an even greater number will be slaughtered when the Republic of Nigeria crushes the revolt of the Ibos of Biafra. Similarly, in recent years the Bahutu have been conducting a "blood bath" policy of extermination against their fellow black men, the Watusi, who for centuries had kept them in slavery. Thus, as a practical matter, many black nationalists could do well to review the writings of James Baldwin, who has so poignantly related the fact that any Negro having meaningful contact with Africans quickly realizes that he is an American.

Going beyond the rhetoric of Black Power, the Report undertakes an in-depth study of the plight of the Negro community. In 1910, some 91 percent of the Negroes in this country lived in the South and only 27 percent lived in cities. By 1967, some 45 percent lived outside of the South and 69 percent lived in cities. The Negro population is growing at a far more rapid rate than the white. Between 1940 and 1960, the white population increased by 34 percent, the black by 46.6 percent; between 1960 and 1966, the white population increased by 7.4 percent, the black by 14.4 percent. Accordingly, in 1950 the Negro population was 10 percent of the nation's total population; in 1966 it was 11.1 percent; and by 1972 it will be 12.5 percent. As a result, the black population of this country is considerably younger than the white population. In 1966, the median age of whites was 29.1 years while for Negroes it was 21.1 years.

Between 1910 and 1967, the Negro population more than doubled, reaching 21.5 million people; the number of Negroes living in cities rose by five times, reaching 14.8 million people; and the Negroes living outside the South increased elevenfold, now 10 million people. The past migration from the South to the North and West and from rural to urban areas has had the effect of concentrating Negroes into the central cities in all regions of the country. The in-migration of blacks to the cities where they are confined by discrimination in bousing or, more subtly, by income restraints has been accompanied by an outward exodus of whites.

The Negro population in the North and West has become so large that it is now natural increase rather than migration that provides the best explanation for the gain in Negro population in these regions. The Commission reveals that in the last sixteen years, 98 percent of the growth in the Negro population has been in metropolitan areas and 86 percent of the increase has been in the central cities of those areas (p. 390). Thus, the growth of the total Negro population bears uniquely on the central cities. 
The concentration of Negroes in the cities has been compounded by the employment problems created by poor schools, stifled occupational aspirations, lack of information and declining job opportunities. As a result, 41.7 percent of the total Negro poor live in the central cities (as opposed to 23.8 percent of the total white poor). ${ }^{7}$ But while 23.2 percent of the white poor are over 65 , only 6.8 percent of the Negro poor are over that age. In 1966, 29.7 million Americans, or 15.3 percent of the total population, were classified as being poor. Although 68.3 percent of this number were whites and 31.7 percent being black, the 20.3 million poor whites represented only 11.9 percent of the total white population while the 9.3 million poor blacks represented 40.6 percent of the total black community.

The Commission relies extensively upon the Department of Labor's new concept of sub-employment as a measure of income deprivation. Until recently, the only figures available for a study of employment conditions were the unemployment and labor force participation rates. As a rule, these indices were for such a broad segment of the labor force that they obfuscated the desperate plight of certain component groups. To fulfill this need for a micro-approach to labor market analysis and for a measure of underemployment, the Department of Labor developed the sub-employment index. The index includes those who are officially classified as unemployed; those who have quit looking for jobs because they believed none were available; those receiving wages that do not provide income sufficient to exceed the poverty level of annual income, and an estimate of the undercounting of males in the official government statistics. Using this device, the Commission estimates that in 1967 the number of Negroes who were sub-employed in the central cities alone was a shocking 1,034,000.

Against the dismal background provided by the income and employment statistics, the tale of woe sketched by the other social statistics comes as no surprise. The prevailing rates of crime, illegitimacy, female heads of household, disease, school dropout, and functional illiteracy serve only to reiterate the story that Franklin Frazier, Michael Harrington, Kenneth Clark, Claude Brown, Charles Silberman, St. Clair Drake, Daniel Moynihan, and so many others have recited before. The Report simply brings the figures up to date and reproduces the same portrait.

The statistics which assure special prominence in the Report are those relating to Negro youth in the age group of 16 to 24 years. Recalling the profile of the "typical rioter," the Report states that there are presently about 583,000 Negro youth in this age category. Of this number, 131,000, or 22.5 percent, are officially classified as unemployed. The Commission estimates that two or three times this number are probably underemployed.

\footnotetext{
7The Commission uses as its criterion for being poor the latest benchmark established by the federal government. That figure for 1967 was $\$ 3,335$ annual income for an urban family of four.
} 
Furthermore, this age group is expected to increase by 1.6 million, or by 40.1 percent, in the next ten years, compared to a growth of 23.5 percent for whites in this bracket. Concerning this development, the Commission states:

"This rapid increase in the young Negro population has important implications for the country. This group has the highest unemployment rate in the nation, commits a relatively high proportion of all crimes, and plays the most significant role in civil disorders" (p. 392).

The statistics in the Report yield a vivid impression of what life is like in the ghetto. Crime is rampant; to keep alive in the area in which many of the perpetrators and most of the victims of crime in the city are found is no easy trick. Health and sanitation problems are acute. High rates of maternal and infant mortality as well as markedly short life expectancies serve as grim reminders of the dreadful plight of human affairs. Exploitation by local merchants is an everyday fact of life. Low-income families who are confronted with higher prices than those found elsewhere in the same city, who are ill equipped to understand high pressure salesmanship, misrepresented prices, exorbitant credit charges, and false warranty promises, and who are plagued by the constant threat of salary garnishment (even after their purchases have been repossessed) present an added dimension of misery and bitterness to the statistical picture of ghetto life.

Thus, by implication, the Commission seems to conclude the whole combination of forces which characterize ghetto life explains why riots suddenly erupt. The institution of the ghetto, along with all the forces which perpetuate it, emerges as the most likely cause of the disorders. For this reason, the Commission minces no words in issuing this indictment: "What white Americans have never fully understood-but what the Negro can never forget-is that white society is deeply implicated in the ghetto. White institutions created it, white institutions maintain it, and white society condones it" (p. 2). Although the Report does not advance a single cause of the riots, it does make clear that as long as segregation and poverty are allowed to entrap millions of citizens in urban ghettos, the riots may be expected to recur. One must conclude, then, that the ghettos must be destroyed in order to put an end to the riots. To tolerate the ghettos, in other words, is to perpetuate riots.

\section{WHAT CAN BE DONE?}

The Report concludes that there are three possible courses of action among which to choose: to pursue the present policies, to establish enrichment programs for the ghettos or to abolish the ghettos by integrating their citizens into society as equal partners. The Commission totally 
rejects the first two choices: the first because it is inadequate and the second because true equality can never be achieved so long as separation is maintained. The only meaningful choice is the course of full integration which simultaneously concentrates greater resources on meeting the problems of the ghetto and enlarges the exit channels to better employment, education, and housing outside the traditional confines of the city ghetto.

The Commission candidly admits that "we have uncovered no startling truths, no unique insights, no simple answers" (p. 483). It also quotes from the salient testimony it received from Dr. Kenneth Clark: "I must again in candor say to you the members of this Commission-it is a kind of Alice in Wonderland-with the same moving picture re-shown over and over again, the same analysis, the same recommendations, and the same inaction" (p. 483).

The Commission's principal recommendations are as follows:

(1) Create two million new jobs during the next three years (550,000 in the first year), half in the public and half in the private sector.

(2) Emphasize on-the-job training (as opposed to classroom training) by both public and private employers, with reimbursement to the latter for all extra costs involved in training the hard-core unemployed.

(3) Increase markedly the efforts to eliminate de facto segregation in the nation's schools through substantial federal assistance to those schools that aggressively seek such an objective.

(4) Improve dramatically the schools serving disadvantaged children through substantial federal funding for year-around compensatory education programs.

(5) Establish uniform national welfare standards which are minimally as high as the annual "poverty level," with federal funds providing at least 90 percent of the required funds.

(6) Enact a program of income supplements "for those who can work and do work" so that incentives will be present for fuller employment, and provide a guaranteed minimum income for those who cannot work.

(7) Pass an enforceable federal open-housing statute to cover the sale or rental of all housing.

(8) Make available to low and moderate income families six million new and renovated units of decent housing within the next five years beginning with 600,000 units within the first year.

Needless to say, to carry these recommendations into effect would be extensive as well as expensive, although the Commission did not place any estimates on the cost of its proposal. However, the potential importance of such a massive application of economic remedies cannot be stressed in strong enough terms. Even if racism could be abolished, the legacy of past deprivation would remain in the form of poor education, stifled aspirations, poor health, squalid living conditions, and the dis- 
proportionate concentration of disadvantaged citizens in menial jobs. In all likelihood, the actual attainment of racial equality is dependent upon success in gaining the economic requisites. The heart of racial equality no doubt lies in the individual's achievement of dignity. In this day and age, however, human dignity often depends on access to a good education, comprehensive health care, meaningful employment, and adequate housing. There can hardly be any doubt that the conversion of these economic goals from slogans into achieved bases for attaining individual dignity should be the first order of concern among social scientists.

In addition to the recommendations listed above, the Commission proposes a battery of measures designed to increase the participation of local citizens in shaping the events that affect their lives. Such structures as neighborhood task forces, neighborhood city halls, community service officers, a "rumor central," and Institutes of Urban Communications are among the specific suggestions offered to solve selected facets of the urban crisis. One should remember, however, that these devices are only the frosting on the cake. Without the massive infusion of funds needed to support the Commission's major proposals and a major commitment by the white community to the desirability of integration as a national goal, improved institutional machinery is useless.

In reality, the call for greater participation by indigenous members of the ghetto in determining of the rules by which they are governed, illustrates a weakness in the Report. The point is that the Commission confuses the rhetoric of Black Power with concept of Black Power. While it explicitly condemns the term, the Commission implicitly endorses most of the vital planks. Greater community participation is actually the core of the Black-Power concept. By calling for "improved political representation," "more effective community participation," "hearings on ghetto problems and enactment of appropriate local legislation," special efforts to recruit, assign, and promote Negro police in ghetto precincts, and school curricula and textbooks more relevant to "the harsh realities of life in the ghetto" and "the contribution of Negroes to the country's culture and history," the Commission is actually endorsing much of the Black-Power platform. As Stokely Carmichael and Charles V. Hamilton have written, "The goal of black self-determination and black self-identity - Black Power-is full participation in the decision-making processes affecting the lives of black people, and recognition of the virtues in themselves as black people." The Report inaccurately equates "Black Power" with "black racism" and when it attacks the latter, it misinterprets the former.

${ }^{8}$ Stokely Carmichael and Charles V. Hamilton, Black Power: The Politics of Liberation in America, New York, 1967, p. 47. 


\section{CONCLUDING OBSERVATIONS}

The response to the Commission's findings is now up to Congress and the American public. The first session of the Ninetieth Congress gave few signs of grasping the scope of the problems or the height of the tensions in the ghettos. This was the Congress that laughingly voted down a meager rat-extermination bill (only to reverse itself a few weeks later after a public outcry), emasculated the National Teachers Corps, appropriated less than half of the minimally requested funds needed to launch the Model Cities program, passed the first truly punitive welfare legislation in the history of this nation, and refused to seat Adam Clayton Powell, the flamboyant but nonetheless duly elected representative from Harlem who had been Chairman of the powerful House Committee on Labor and Education. This Congress also sought to exclude the employees of the Office of Economic Opportunity (OEO) from the pay increase granted all other federal employees, provided even fewer funds than the OEO had requested (doing so five and one-half months after the fiscal year had begun, which meant that many new projects were never launched, the expansion of successful programs was postponed, and all ongoing programs were held in uncertain abeyance), and passed the "city hall amendment" to the Economic Opportunity Act which now permits local governmental bodies to declare themselves the community action agency and thereby extend control by local politicians over the local anti-poverty effort. Precisely because of the callous indifference of the Ninetieth Congress to the magnitude and urgency of the needs of our cities, Dr. King planned his "poor people's march" on Washington. As he stated, "You can say that the goal of this campaign will be to expose Congress."

To date the significant civil-rights legislation has been virtually costless to the federal treasury. The Civil Rights Act of 1964 calls for equal access to public accommodations and for equal employment opportunity; the Civil Rights Act of 1965 provides voting-rights safeguards; and the Civil Rights Act of 1968 enacts a policy of "fair housing." As important as these statutory goals are, they are void of true significance if parallel programs are not initiated to increase the earning power of black America. In the past the barriers to integration have been social and political; today they are increasingly economic. To overcome these economic barriers will cost billions of dollars. Improved housing, education, employment, and health protection bear expensive price tags. Local governments cannot even begin to provide the needed funds. Most of the cities which experienced disorders are already at the legal bonding limit. Clearly property taxes cannot bear the burden. Hence, there is great need for a re-ordering of federal expenditure priorities, for developing new experimental approaches, for a personal dedication by a

\footnotetext{
"“Dr. King's March on Washington, Part II," New York Times Magazine, March 31 , 1968, p. 60 .
} 
sizable portion of the electorate to the goals of equal economic opportunity, and for leadership at all levels of government committed to the eradication of ghettos. The issue is eloquently highlighted by the Commission: "There can be no higher priority for national action and no higher claim on the nation's conscience" (p. 2).

Since the white community has created, maintained, and condoned a system of secondary status for its black citizens, it cannot escape from the consequences of its own actions. However, the real issue for this generation of Americans is not to place the blame but rather to accept the responsibility for corrective action. The economic and political power of this nation remains largely in the control of whites. Black citizens can rise in violent protest but they cannot solve their dilemmas alone. Pleas to blacks for restraint or for "law and order" are no more useful as preventatives than are the passage of "anti-riot bills" by Congress and the branding of militants as "agitators" by the press. The best advice given in opposition to riots was probably that of Dr. King, who said: "Riots increase the fears of the whites and relieve them of their guilt."10

The Commission's Report should be read by everyone. But in true candor, one must add that it has all been said before. In fact, the 1967 Report of the U.S. Civil Rights Commission provides as many useful insights. Appropriately, the document was entitled A Time to Listen, A Time to Act. If ever this nation needs to replace listening, talking, and documenting with action, that time is now.

${ }^{10}$ Ibid., p. 62. 